\title{
Razvijanje vodstvene kompetentnosti
}

dr. Edvard

Konrad

Filozofska

fakulteta

$v$ Ljubljani
$\mathrm{U}$

činkovito delovanje različnih vrst organizacij je precej odvisno od kakovosti vodenja. Prizadevanja za izboljšanje kakovosti vodenja so zato $\mathrm{v}$ zadnjih desetletjih zelo intenzivna na raziskovalnem in tudi na praktičnem področju. Mnoge organizacije, ki so nezadovoljne s kakovostjo tržno dostopnih izobraževalnih sistemov, razvijajo svoje programe za oblikovanje kompetentnih managerjev. Boyatzis (1996) meni, da se $\mathrm{v}$ svetu porabi $\mathrm{v}$ te namene vsako leto okoli 37 milijard dolarjev, le približno 10-15 odstotkov managerjev pa v praksi konsistentno izkazuje nadpovprečno uspešnost.

Kako priti do uspešnih vodij, ali je vodstvene kompetentnosti mogoče razvijati in kako, so vprašanja, ki so bila vedno aktualna. Novejše izkušnje kažejo, da na ta vprašanja ni enostavnih odgovorov. Namen tega sestavka je osvetliti pomen pojma vodstvenih kompetentnosti za problematiko izobraževanja managerjev. Zanima nas, od česa je odvisna uspešnost vodenja in kakšno vlogo imajo pri tem vodstvene kompetentnosti, pa tudi, kako se te izražajo pri delu in s kakšnimi pristopi jih je mogoče razvijati.

\section{ANALIZA VODSTVENEGA DELA}

Da bi bolje razumeli, kako vodje obvladujejo omenjene organizacijske probleme, je treba analizirati delo vodstvenega delavca. Koristni pojmovni okvir za takšno analizo je členitev dela, ki jo je predlagal Mintzberg (1973). Po njegovih raziskavah je delo vodje sestavljeno iz treh skupin vlog:

\section{Interpersonalne vloge}

- Predstojnik. Vodja je simbolični predstavnik določene organizacijske enote in kot tak odgovoren, da opravlja različne socialne, pravne in ceremonialne dolžnosti.

- Vodja v ožjem pomenu. Odgovoren je za motiviranje, nadzor, kadrovanje, usposabljanje in napredovanje podrejenih. Pri tem delu mu sicer lahko pomagajo specializirane strokovne službe, teh odgovornosti pa se ne more nikoli popolnoma otresti.

- Povezovalec. Vodja vzdržuje stike s številnimi posamezniki zunaj svoje organizacijske enote. Čim višji je njegov status, tem pogostejše so njegove tovrstne interakcije.

Naštete interpersonalne vloge omogočajo vodji privilegiran pristop do številnih informacij, ki so vitalne za razumevanje funkcioniranja organizacije. Zato se mora izkazovati $v$ različnih informacijskih vlogah.

\section{Informacijske vloge}

- Monitor. Vodja išče, zbira in analizira različne informacije, da bi bolje spoznal svojo organizacijo in okolje. Te informacije so marsikdaj slabo strukturirane, zato jih vodja obvladuje le tako, da razvije lastni dokumentacijski sistem, pri čemer so mu lahko v oporo formalni informacijski sistemi.

- Diseminator. Vodja je odgovoren, da določene informacije prenaša na svoje sodelavce, in skrbi zato, da so ustrezno informirani.

- Govornik. Ker od vodje pričakujemo, da je najbolje informiran o področju, kjer deluje, 
spada med njegove dolžnosti tudi zavzemanje določenih stališč, s čimer vpliva na zaposlene $\mathrm{v}$ organizaciji in tudi zunaj nje.

Zaradi svojih informacijskih vlog je vodja bolje informiran in ima zato tudi sorazmerno večji vpliv pri odločanju. To se kaže v ustreznih vlogah.

\section{Vloge pri odločanju}

- Podjetnik. Vodja je inovator: nenehno načrtuje in sproža spremembe $\mathrm{v}$ organizaciji ter išče nove priložnosti in probleme.

- Obravnavanje motenj. Vodja je odgovoren za korektivne akcije, ko se organizacija znajde $\mathrm{v}$ nepričakovanih težavah. Za odpravljanje specifičnih motenj ima vsaka organizacija posebne strokovne službe. Vodje se ukvarjajo predvsem $\mathrm{z}$ nespecifičnimi motnjami $v$ delovnem procesu.

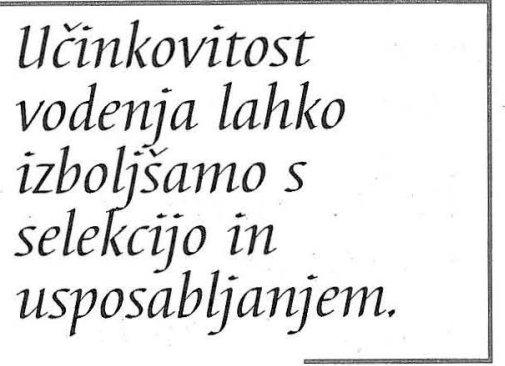

- Alokacija virov. Vodja je odgovoren $\mathrm{za}$ razporejanje sredstev. Ta odgovornost za upravljanje različnih sredstev implicira njegovo sodelovanje pri ključnih odločitvah, ki zadevajo organizacijsko enoto.

- Pogajalec. Vodja predstavlja svojo organizacijo kot stranka pri dogovarjanju z različnimi posamezniki in organizacijami, s katerimi poslovno sodeluje.

Iz omenjenih značilnosti dela je mogoče sklepati o različnih sposobnostih, spretnostih, znanju in motivaciji, potrebnih za vodstveno delo. Številne raziskave vodenja kažejo na to, da so osebnostne značilnosti deloma povezane z učinkovitostjo vodenja (Yukl, 1996). Eden izmed pomembnih razlogov zato, da osebnostne lastnosti niso bolj povezane $\mathrm{z}$ učinkovitostjo vodenja, izvira iz problemov pri določanju delovne uspešnosti vodij. Slednja se namreč ne določa samo individualno, temveč predvsem na podlagi rezultatov, ki jih dosega njegova organizacijska enota. Akcije vodje morajo dolgoročno podpirati funkcioniranje organizacijske enote, za katero je vodja odgovoren (Campbell, Dunnette, Lawler \& Weick, 1970).

Seveda so različne osebnostne lastnosti vodje še vedno ključno gibalo njegovega ravnanja. Za izboljšanje učinkovitosti vodenja obstajata dve osnovni poti: selekcija in usposabljanje. Oba načina se v praksi dopolnjujeta. Pri selekciji in usposabljanju je zelo koristno celostno obravnavati različne osebnostne lastnosti, kot so sposobnosti, spretnosti, znanje, motivacija in osebnostne poteze. Takšen pristop nam omogoča pojem kompetentnosti.

\section{KLJUČNE OBLIKE VODSTVENE KOMPETENTNOSTI}

Kaj pomeni biti kompetenten? Po SSKJ (1975, 4. del, str. 388) je kompetenten tisti, ki temeljito pozna, obvlada določeno področje, je zanj usposobljen in poklican. Psihološka analiza kompetentnosti kaže, da je ta konstrukt mešanica motivov, osebnostnih potez, spretnosti, znanja, sposobnosti in samopodobe, pomembnih za opravljanje dela na določenem področju.

Pojem kompetentnost se v več pogledih razlikuje od sorodnega pojma spretnosti.

1. Kompetentnost se izraža ne samo na vedenjski, temveč tudi na kognitivni ravni.

2. Kompetentnost je pomembna pri opravljanju neprogramiranih, nerutinskih nalog.

3. Kompetentnost se izkaže pri delu v kompleksnem in spremenljivem okolju.

4. Kompetentnost je mogoče prenašati na druge naloge in vloge.

5. Kompetentnost je povezana $\mathrm{z}$ notranjo motivacijo.

6. Kompetentnost je mogoče uresničevati tako rekoč brez meja. 
Kompetentnost za vodstveno delo je Boyatzis (1982) analiziral tako, da je primerjal kritične incidente uspešnih in neuspešnih managerjev. Ugotovil je, da $\mathrm{k}$ razliki med uspehom in neuspehom na tem področju pripomorejo te kompetentnosti:

1. orientacija na uspešnost,

2. interes za vplivanje na druge,

3. proaktivnost,

4. samozaupanje,

5. komunikacijske spretnosti,

6. induktivno rezoniranje in kreativnost,

7. diagnostična uporaba konceptov in deduktivno rezoniranje,

8. uporaba socializirane moči,

9. obvladovanje skupinskih procesov.

Za praktično delo ne zadostuje, da samo razumemo pojem kompetentnosti, temveč ga je treba opredeliti za ustrezno področje delovanja. Zato so potrebne ustrezne raziskave.

\section{RAZVIJANJE VODSTVENE KOMPETENTNOSTI}

Pojem kompetentnosti presega dilemo, ali je dober vodja »rojen« ali »narejen«. Če hočemo priti do kompetentnih vodij, je potrebno oboje. Nekatere osebnostne značilnosti so večinoma prirojene in jih s kasnejšim učenjem ne moremo veliko spreminjati. Upoštevati jih je mogoče pri kadrovski selekciji managerjev. Očitno pri tem ne gre samo za selekcijo, ki jo opravljajo organizacije po določenih načelih za vsa delovna mesta, temveč predvsem za samoselekcijo, ko jo opravljajo posamezniki, ko realizirajo svojo delovno kariero (Konrad, 1976). Investiranje v vodstveno kariero je v bistvu poklicno odločanje. Vodstvena kompetentnost je ena izmed devetih splošnih karier- nih orientacij, ki jih Schein (1996) imenuje karierna sidra.

Učenje vodstvene kompetentnosti poteka $\mathrm{v}$ okviru družbene, družinske in organizacijske socializacije. Procesi socializacije so tako tesno povezani z vsakdanjim življenjem, da jih večkrat niti ne opazimo. Osebnostne značilnosti in oblike vedenja, ki se jih naučimo $\mathrm{v}$ procesu zgodnje socializacije, se zdijo večkrat prirojene. Seveda se v procesu socializacije naučimo tudi takšnih oblik vedenja in miselnih vzorcev, ki nas lahko ovirajo pri doseganju vodstvene kompetentnosti. Primer za to so različne miselne predpostavke, ki po Argyrisu in Schonu (1978) ustvarjajo diskrepance med teorijami ki jih posameznik deklarira, in tistimi, ki jih dejansko uporablja v praksi. Takšnih diskrepanc, ki so pogosto tudi podzavestne, ne moremo premagovati s površinskim učenjem različnih tehnik. Za to je potrebno bolj poglobljeno učenje, ki ga omenjena avtorja imenujeta učenje $\mathrm{z}$ dvojno zanko.

Procesi učenja, ki so povezani $\mathrm{z}$ razvojem vodstvene kompetentnosti, so torej dolgotrajni in poglobljeni. Teoretično takšno učenje ne more temeljiti samo na enostavnih behaviorističnih načelih, ki so sicer zelo učinkovita pri razvijanju veščin. Učenje kompetentnosti se opi-
Večina sestavin vodstvene kompetentnostije naučna. ra bolj na načela socialne kognitivne teorije, ki jih je zasnoval Bandura (2001). To učenje je učinkovitejše, če poteka $v$ učeči se organizaciji (Senge, 1990).

Omenjena načela ni lahko vgraditi v praktične izobraževalne programe, ker se marsikdaj ne ujemajo s standardno prakso dobro strukturiranih programov, ki so jih vajeni strokovnjaki in konzultanti s področja izobraževanja in razvijanja človeških virov. S poudarjanjem individualizacije, pluralizma, sprejemljivosti za eksperimentiranje in spremembe ter toleriranja negotovosti namreč pogosto prihajajo $\mathrm{v}$ 
Izkušnje in rezultati raziskav nakazujejo, da je treba za razvoj vodstvenih kompetenc upoštevati naslednja izhodišča:

1. Za razvijanje vodstvenih kompetenc je treba razviti individualizirane programe za diagnozo in spreminjanje posameznikov. Ti programi se morajo povezati z njegovimi vizijami in vrednotami glede želene prihodnosti. Programi morajo omogočiti diagnozo močnih in šibkih točk v pogledu kompetentnosti, pa tudi potreb glede nihovega razvoja v prihodnosti, posamezniku pa smiseln in osebno naravnan proces načrtovanja in lastnega razvoja.

2. Razvoj kompetentnosti zahteva interpersonalno podporo, ki omogoča posamezniku ekplorirati svoje poglede na prihodnost, diagnosticirati sedanje stanje in razvijati načrte za svoje delovanje. Ta podpora je verjetnejša, če je program razvoja kompetentnosti povezan s programom za organizacijski razVoj.

3. Razvoj kompetentnosti zahteva priložnosti za eksperimentiranje in raziskovanje pri uporabi lastne kompetentnosti in znanja $v$ delovnih razmerah.

konflikt z zahtevami po učinkovitosti in stroških. Po drugi strani pa zahtevajo od posameznikov, ki hočejo razviti njihovo vodstveno kompetentnost, veliko odgovornosti in dela.

\section{LITERATURA}

Glej spletne strani: edvard.konrad@ff.uni-lj.si 